\title{
Smelling Good Enough to Kill! Plant Essential Oils and their Insecticidal Activity
}

\author{
Fardad Firooznia, Maryam Said, Gavin Balkaran, and Jhunior Morillo
}

\author{
City College of New York, Department of Biology,160 Convent Ave, Marshak J-526, New York NY \\ 10031 USA \\ (ffirooznia@ccny.cuny.edu)
}

\begin{abstract}
Bean beetles, in the genus Callosobruchus, are agricultural pests in tropical and subtropical regions of Africa and Asia. Organophosphate insecticides such as malaoxon have been used to control insect pests such as bean beetles. There is increased interest in using natural insecticides to replace chemicals such as malaoxon because of increasing levels of insecticide resistance in different insect pests as well as concerns about the effects of these chemicals on human health and unintended effects on non-target organisms. Essential oils from aromatic plant species contain varying combinations of different compounds. Due to their different compositions, essential oils from some plant species may act as more potent insecticides than essential oils from other plant species. In this lab exercise, students studied the effectiveness of essential oils from different aromatic plants as natural insecticides against the bean beetle Callosobruchus maculatus. In the process, the students carried out a literature search, designed and carried out the experiment, analyzed their data, and presented their findings. Given the paucity of published data on the insecticidal effects of plant essential oils on bean beetles, the research carried by the students generated novel data.
\end{abstract}

Keywords: Bean beetles (Callosobruchus), natural insecticides, plant essential oils

Link to Original Poster File: https://doi.org/10.37590/able.v41.poster68

\section{Mission, Review Process \& Disclaimer}

The Association for Biology Laboratory Education (ABLE) was founded in 1979 to promote information exchange among university and college educators actively concerned with teaching biology in a laboratory setting. The focus of ABLE is to improve the undergraduate biology laboratory experience by promoting the development and dissemination of interesting, innovative, and reliable laboratory exercises. For more information about ABLE, please visit http://www.ableweb.org/.

Advances in Biology Laboratory Education is the peer-reviewed publication of the conference of the Association for Biology Laboratory Education. Published articles and extended abstracts are evaluated and selected by a committee prior to presentation at the conference, peer-reviewed by participants at the conference, and edited by members of the ABLE Editorial Board. Published abstracts are evaluated and selected by a committee prior to presentation at the conference.

\section{Citing This Article}

Firooznia F, Said M, Balkaran G, Morillo J. 2020. Smelling good enough to kill! plant essential oils and their insecticidal activity. Article $68 \mathrm{In}$ : McMahon K, editor. Advances in biology laboratory education. Volume 41. Publication of the 41st Conference of the Association for Biology Laboratory Education (ABLE). https://doi.org/10.37590/ able.v41.abs68

Compilation (C) 2020 by the Association for Biology Laboratory Education, ISBN 1-890444-17-0. All rights reserved. No part of this publication may be reproduced, stored in a retrieval system, or transmitted, in any form or by any means, electronic, mechanical, photocopying, recording, or otherwise, without the prior written permission of the copyright owner.

ABLE strongly encourages individuals to use the exercises in this volume in their teaching program. If this exercise is used solely at one's own institution with no intent for profit, it is excluded from the preceding copyright restriction, unless otherwise noted on the copyright notice of the individual chapter in this volume. Proper credit to this publication must be included in your laboratory outline for each use; a sample citation is given above. 